\title{
Assessing the Impact of Relationship Length in the SMEs and Bank Association
}

\author{
Mark Ojeme ${ }^{1}$ \\ ${ }^{1}$ Lecturer in Marketing, Department of Strategic Management and Marketing, Faculty of Business and Law, De \\ Montfort University, Leicester, United Kingdom \\ Correspondence: Mark Ojeme, Department of Strategic Management and Marketing, Faculty of Business and \\ Law, De Montfort University, Leicester, United Kingdom. Tel: 44-116-250-6487. E-mail: \\ mark.ojeme@yahoo.com
}

Received: August 30, 2017

Accepted: September 25, 2017 Online Published: September 30, 2017

doi:10.5539/ijms.v9n5p17

URL: http://doi.org/10.5539/ijms.v9n5p17

\begin{abstract}
Despite the importance of satisfaction, loyalty and relationship length in the literature, there is very little evidence of studies within the Nigerian Business to Business (B2B) Relationship terrain. This paper seeks to investigate the effect of relationship length on SMEs association with their banks in Nigeria. Measurement Items were adapted from various scale sets presented in existing studies were combined to investigate the B2B relationship context. Data were collected from 221 SMEs via a self-administered questionnaire completed either by the SME owner or senior manager with responsibility for relationship with their bank, providing 199 usable records. Principal Component Exploratory Analysis (PCA) was used to determine the underlying data structure, with subsequent deployment of Cronbach's alpha as a post-hoc assessment of the internal reliability of the retained factors. Subsequently, regression analysis was employed to determine the impact of satisfaction on loyalty in a short and long term relationship contexts. The analysis presented suggests that the SMEs' had evidence of been satisfied with their bank, however, the regression analysis for both short and long term relationship length were both significant in impacting their loyalty towards their bank. The originality of this paper lies in the investigation of a B2B relationship involving SMEs and banks within a relationship context that hitherto was unknown and the validation of relevant relationship building blocks.
\end{abstract}

Keywords: SMEs, banks, satisfaction, relationship length, loyalty and Nigeria

\section{Introduction}

Relationship marketing (RM) is recognised as a major paradigm shift in marketing activities from the late 1980s, superseding transaction marketing dominance in the early 1960s (Gummesson, 2002; Gronroos, 1994; Palmatier et al., 2006; Sheth \& Parvatiyar, 2002). Since the advent of RM, there have been prolific studies undertaken to understand the dynamics of RM and its implications to theory and businesses (Beck, Chapman, \& Palmatier, 2015; Zhang et al., 2016).

In terms of areas and focus, a significant amount of studies have examined different driving factors of RM with particular focus to key driving factors on satisfaction, trust, commitment and loyalty (Garbarino \& Johnson, 1999; Fullerton, 2011) as crucial for building and sustaining long term relationship (Beck, Chapman, \& Palmatier, 2015; Zhang et al., 2016). Another interesting and important factor to RM is relationship length (RL). The concept of RL relates to the number of years two parties have been engaged in meaningful business exchanges (Wang \& Wu, 2012). There is evidence in the literature on the importance of RL (Wang \& Wu, 2012). In particular, the presence of longer relationship length is considered to strengthen a relationship especially as a key for building loyalty (Wang \& $\mathrm{Wu}, 2012$ ).

Whist studies have shown the significance of RL in various relationship contexts, there is very little evidence of studies within the dynamics of Small and Medium Enterprises (SMEs) and bank relationship, despite the importance of SMEs to the economy. SMEs have made substantial contribution to different economies GDP in both developed and developing societies. In Nigeria, SMEs including micro businesses account for 32 million employees and contribute $46 \%$ of GDP (NBS and SMEDAN, 2010). On the average, Nigerian SME sector provides $50 \%$ of Nigeria's employment and $50 \%$ of its industrial output (Ariyo, 2008). 
The relationship between Nigerian banks and SMEs has been considered to be modest, considering the decline of financial support to the latter and financial crises that has affected the former. This modest record of performance can be accounted for by an absence of financial regulation, poor banking skills, fraudulent practice, over reliance on the state sector and weak capitalisation (Uche \& Ehikwe, 2001; Beck et al., 2005; Agbonkpolor, 2010).

Based on the evidence of strained relationship between the Nigerian Banks and SMEs, and the lack of evidence of RL study in developing economies with particular focus in Nigeria, this study aims to examine the influence of SMEs satisfaction and loyalty towards their bank and the impact of relationship length within the specific context. The study aims to contribute to the body of knowledge on RM and RL by extending an investigation into a new relationship terrain which is lacking in the academic literature.

The next section examines the key component of satisfaction and loyalty, whilst subsequent sections will present the study's data, analysis, findings, and contribution to the body of knowledge and recommendation to business practices.

\section{Literature Review}

\subsection{Relationship Satisfaction}

The literature has two prevalent approaches in the illumination of customer satisfaction. One approach is the transaction specific satisfaction and the overall satisfaction (Bodet, 2008; Lam et al., 2004; Johnson et al., 2001; Jones \& Suh, 2000; Olsen, 2007; Veloutsou et al., 2005). The other approach is the confirmation and disconfirmation paradigm (Homburg et al., 2001; Homburg, Koschate, \& Hoyer, 2005; Oliver, 1997; Patterson et al., 1996). The concept of transaction-specific satisfaction relates to a customer evaluation of one time encounter with various aspects associated with the business service provider (Jones \& Suh, 2000). Various elements of customers' evaluation in specific encounters comprises of the quality of the service, quality of the product and price of the services offered by the service provider (Andaleeb \& Conway, 2006; Spreng \& Mackoy, 1996). This approach enables the service provider to gain valuable insights into the relevant service offerings and products that drives customer satisfaction (Johnson, Anderson, \& Fornell, 1995; Veloutsou et al. 2005).

In contrast to the transaction-specific approach, the cumulative approach delineates satisfaction from the summative perspective of customer evaluation of the services provided (Homburg et al., 2005; Johnson et al., 2001). While the cumulative perspective differs from the specific transaction approach, the latter is essential in the formation of the former. This is because cumulative satisfaction is aggregated based on the overall customer encounter on each occasion with the service provider. In other words, satisfaction is an ongoing and dynamic process (Fournier \& Mick, 1999).

Lam et al. (2004, p. 295), observe that "overall satisfaction is a more fundamental indicator of the firm's past, current, and future performance". Most companies rely on cumulative satisfaction because it has a better reflection of the true psychological state of the customer to a service provider and is relatively stable overtime (Lam et al., 2004; Veloutsou et al., 2005). That is, customer state of mind about a product builds over time because of the various encounters with the services (Oliva, Oliver, \& MacMillan, 1992; Veloutsou et al., 2005).

In the customer satisfaction literature, the confirmation and disconfirmation framework explicates how customer satisfaction emerges (Fournier \& Mick, 1999; Homburg et al., 2005; Oliva et al., 1992). Customer satisfaction relates closely to how the performance of the services is able to fulfil the anticipated expectations (Evanschitzky et al., 2012; Oliva et al., 1992; Roman, 2003). With this performance and expectation evaluation, there are three fundamental perspectives to satisfaction (Oliva et al., 1992). The consumption of services is equivalent with the expectations (standards), in this case, confirmation of performance is established (Oliva et al., 1992; Roman, 2003). On the other hand, an expectation that is below the performance of the services leads to negative disconfirmation, while service performance above the customers' expectation level leads to positive disconfirmation (Oliver, 1980; Oliver 1997). Cogently, confirmation and positive disconfirmation will most likely influence customer to a state of satisfaction with a service provider (Oliver, 1997; Roman. 2003). In situation when customers have a positive disconfirmation, satisfaction will be the resultant outcome, whereas, in situation of negative disconfirmation, customer dissatisfaction and discontentment represents the possible resultant effects (Oliver, 1997; Roman, 2003).

The review of the literature suggests various academic definitions of customer satisfaction. There is a dominant definition of customer satisfaction being related to works by Oliver (1997). Oliver (1997) reviewed the extant literature to provide a comprehensive definition of satisfaction consistent with theoretical and empirical evidence. In the author's definition, customer satisfaction is the "consumer's fulfilment response. It is a judgement that a product or service feature, or the product or service itself, provided (or is providing) a pleasurable level of 
consumption-related fulfilment, including levels of under or over fulfilment" (Oliver, 1997, p. 13). In this definition, two important notions are evident. First, satisfaction is pleasurable, which implies that satisfaction gives pleasure and reduces discomfort when a problem is solved by consumption of product or the utility of a service. The second point to note is that of fulfilment. Oliver (1997), states that the reference to fulfilment in his definition highlights that a goal exists and needs to be filled.

Similar to Oliver's definition of customer satisfaction, other academic studies have defined satisfaction as documented in Table 1:

Table 1. Various authors' definition of satisfaction

\begin{tabular}{|c|c|}
\hline Authors & Definition attributes \\
\hline Anderson \& James (1984, p. 66) & $\begin{array}{l}\text { "define customer satisfaction as the "positive affective state resulting from the appraisal of } \\
\text { all aspect of a firms working relationship with another firm". }\end{array}$ \\
\hline Anderson et al. $(1994$, p. 54$)$ & $\begin{array}{l}\text { "viewed customer satisfaction as an "overall evaluation based on the total purchase and } \\
\text { consumption experience with a good or service over time". }\end{array}$ \\
\hline Hellier et al. (2003, p. 1765) & $\begin{array}{l}\text { "defined customer satisfaction as the "degree of overall pleasure or contentment felt by the } \\
\text { customer, resulting from the ability of the service to fulfil the customer's desires, expectations } \\
\text { and needs in relation to the service". }\end{array}$ \\
\hline Homburg \& Stock (2004, p. 146) & $\begin{array}{l}\text { Defined satisfaction as "an affective state, that is the emotional reaction to an experience or a } \\
\text { sequence of experience with a supplier". }\end{array}$ \\
\hline Olsen $(2007$, p. 320$)$ & $\begin{array}{l}\text { "defines satisfaction "as a consumer's personal and overall evaluation of satisfaction and } \\
\text { pleasure with a given product category and as a cumulative rather a transaction-specific } \\
\text { construct". }\end{array}$ \\
\hline
\end{tabular}

Within the B2B research settings, the definition provided by Anderson \& James (1984) appears to be frequently used in the literature (Garbarino \& Johnson, 1999; Geyskens et al., 1999; Lam et al., 2004; Roman, 2003). This is because the definition identifies satisfaction from a cumulative perspective and in the setting of a business relationship.

\subsection{Loyalty}

Academics and practitioners in the marketing arena are to a large extent in agreement regarding the relevance of customer loyalty to a business (Beerli et al., 2004; Gummerus et al., 2004, Jones et al., 2007). Loyalty of customers is recognised to have the propensity to increase business sales and profits (Evanschitzky et al., 2012; Reichheld, 2003; 2006) and reduce cost of operations (Reichheld \& Teal, 1996). Customer loyalty is also considered to be essential from a business point of view (Bove \& Johnson, 2000), although the actual conceptualisation of customer loyalty has suffered a similar fate as customer commitment (Ball et al., 2004). That is, there is evidence of inconsistencies in relation to the conceptualisation and dimensionality of loyalty concept.

The inconsistencies in the definition of loyalty are reflected in three different perspectives in the literature (Dimitriades, 2006; Knox \& Walker, 2001; Rauyruen \& Miller, 2007). These are the behavioural perspective (Ehrenberg \& Goodhardt, 2000; Olsen, 2007; Rauyruen et al., 2009), the attitudinal perspective (Shankar et al., 2003), and the composite perspectives (Ball et al., 2004; Bell \& Eisingerich, 2007; Day, 1969; Dick \& Basu, 1994; Kumar \& Shah, 2004; Oliver, 1999). The composite approach to loyalty integrates both the behavioural and attitudinal perspectives.

In the behavioural literature, academic scholars are unanimous in their belief that behavioural loyalty is centred on repeat purchasing behaviour by consumers (Aydin Ozer \& Arasil, 2005). Academics that oppose the behavioural approach to customer loyalty have identified some of the inherent flaws in the conceptualisation of loyalty as regular repeat behaviour of customers (Dick \& Basu, 1994; Oliver, 1999). The problem with the behavioural perspective of customer loyalty is that it is not clearly understood whether the repeat buying is motivated by habit, situational reasons or psychological factors (Dick \& Basu, 1994; Odin et al., 2001). For illustration, Dick \& Basu (1994, p. 100) stated that "high repeat purchase may reflect situational constraints, such as brands stocked by retailers, whereas low repeat purchase may simply indicate different usage situations, variety seeking, or lack of brand preferences within a buying unit". Based on the difficulty of predicting high and low sales, it would be difficult for a company to influence the repeat buying behaviour of customers since management has little understanding of what is influencing continuous patronage (Odin et al., 2001).

Contrasting the repeat buying behaviour is the attitudinal approach. This approach to the study of loyalty allows 
for customers to rate their level of preference for the brand or services (Knox \& Walker, 2001). The attitudinal approach to loyalty focuses on the psychological dimensions of customer attitude to the service provider such as long term commitment of a customer to the organisation, which cannot be inferred by merely observing customer repeat purchase behaviour (Auh et al., 2007; Shankar et al., 2003).

A different perspective to the attitudinal or behavioural loyalty approach is the composite loyalty perspective (Dick \& Basu, 1994; Hutchinson et al., 2011; Oliver, 1997, 1999; Wallace, Giese, \& Johnson, 2004). This approach enables the integration of both the attitudinal and behavioural elements in the conceptualisation of loyalty (Caceres, \& Paparoidamis, 2007). Although there are numerous definitions of composite loyalty, the definitions provided by Jacoby \& Kyner (1973); Dick \& Basu (1994); and Oliver (1999) loyalty studies appear to have become the fundamental framework in the operationalisation of loyalty in the extant literature because these scholars' definition of loyalty all have a common theme in the operationalisation of loyalty as both an attitudinal and behavioural concept.

Jacoby \& Kyner (1973) considered a set of six necessary and collectively sufficient conditions to operationalise loyalty. According to the authors, loyalty is "(1) the biased (i.e non-random), (2) beh....i[avioural response (i.e., purchase), (3) expressed over time, (4) by some decision-making unit, (5) with respect to one or more alternative brands out of a set of such brands, and (6) is a function of psychological (decision making, evaluative) processes" (Jacoby \& Kyner, 1973, p. 2).

The authors' definition combines both repeating purchasing behaviour towards a brand and psychological evaluation of the decision making process (Knox \& Walker, 2001). According to Bloemer \& Kasper (1995), decision making and evaluative processes are the two fundamental elements of loyalty conceptualisation which distinguish loyalty from the behavioural loyalty of repeat purchasing. That is, the absence of a decision making process and evaluation as part of customer loyalty would limit and construe loyalty as spurious loyalty of repeated purchasing of the same brand or portfolio of brands (Bloemer \& Kasper, 1995). The conceptualisation of loyalty to have the dimensions of attitude and behaviour identifies loyalty as truly in existence when the consumer does not only purchase the brand or utilise the service but considers his actions and makes a decision to act in favour of the company offering (Bloemer \& Kasper, 1995; Chaudhuri \& Holbrook, 2001; Day, 1969; Dick \& Basu, 1994; Oliver, 1999).

\section{Study Design and Data Analysis}

The study considered two scale sets measuring both satisfaction and loyalty. The measurement items for overall satisfaction adopted in this study originated from the work of Lam et al. (2004) and Oliver (1980) from the retailer and supplier business relationship. These satisfaction items have been extensively applied in marketing research especially in B2B relationship contexts (Cater \& Zabkar, 2009; Garbarino \& Johnson, 1999). Item 1 measures the SMEs' perception of the overall satisfaction towards their banks, Item 2 measures the SMEs' perception of their happiness with their bank. Item 3 measures the SMEs' expectations of the services delivered. Finally, Item 4 measures how fairly the SMEs perceive the treatment received from their bank. For loyalty, 8 items were adopted in this study measuring advocacy and repurchase intention. For advocacy, Items 1, 2 and 3 measure positive recommendations to other people, other companies and business partners, Item 4 measures recommendation emanating from business discussions. The measuring items originate from the scale development on advocacy by Zeithaml et al. (1996). Item 4 originates from Gremler \& Gwinner (2000). All of these items have been applied in bank services research (Bloemer et al., 2007; Fullerton, 2011).

The adapted items for repurchase intention originate from Boulding et al. (1993) and Zeithaml et al. (1996). These items have been extensively used in marketing studies including the banking context (Bell \& Eisingerich, 2007). Items used for repurchase intention measures the SMEs consideration of using same retail bank for the new few years. The scales were subject to some adaptation to fit the context of this study. All items scaled were measured using a 7-point Likert scale ranging from very strongly disagree (1) via neutral (4) to very strongly agree (7).

Prior to survey administration, the instrument was subject to a pilot assessment. This was undertaken to ensure clarity and understanding by the respondents of the presented measurement items. The respondents in each case, senior managers, were asked to complete the questionnaire with the objective of identifying any technical words that may be perceived to be difficult to understand. Senior managers were targeted in the business because they were the key employees responsible for the banking relationship within their respective organisations. The outcome indicated sufficient level of understanding and clarity, with a reasonable time of completion of between 10 to 15 minutes for each of the participants.

The sampling setting of this research was derived from the National Bureau of Statistics (NBS) and Small and 
Medium Enterprises Development Agency of Nigeria (SMEDAN) official statistics published in 2010. The SMEs' population in Nigeria comprises almost 23,000 organisations, adhering to between 10 to 199 employees and having total assets between $5-500 \mathrm{~m}$ Naira ( $£ 20 \mathrm{~K}-£ 2 \mathrm{~m}$ UK Sterling). Those participating were targeted using business-district based cluster sampling, with 310 questionnaires being distributed amongst SMEs located in four Nigerian states. The states chosen were Lagos, Edo, Delta and Ebonyi state covering three geographical regions in Nigeria. These states were chosen because they are home to a relatively high numbers of SMEs in their zones and are located in different regions in Nigeria to ensure a level of regional representation of SMEs country-wide. A self-administered questionnaire was used in the study, further supported by a small team of research assistants directed by this study's lead author. The presence of the research assistants was to enhance participation by offering clarification of particular questions to the respondents, and by doing so, ensuring full completion of the presented questionnaire and higher levels of individual SME participation.

A simple random approach was used which involved selecting businesses within the clustered business areas in each of the identified districts. The researcher and his team approached businesses on a random basis to make enquiry about the number of employees in the organisation. At this point, only businesses who stated that they had employees within the definitional framework of SMEs (10-199 employees) and had a bank account were asked to participate in this research survey. The particular person that participated in the survey was in most cases the business owners who also functioned as the SME's Managing Director. The rationale for their participation was of their responsibility for the banking relationship within their organisation.

In total, 221 questionnaires were returned after the final collection process, representing a response rate of $71 \%$. The high level of response rate can somewhat be attributed to the collectivist culture of the Nigerian society (Ogba, 2008), with the willingness for most companies contacted to participate in this study. From the 221 collected questionnaires, 22 were considered unusable due to incompleteness; reducing the useable data set to 199 records.

The study focus was to access the impact of relationship length on SMEs satisfaction to their banks in Nigeria. To achieve this aim, the study followed the analysis approach of Wang \& Wu (2012) by dividing the data size of the survey demographic into short and long term relationship length. Short term relationship comprises of established banking relationships less than five years with their bank. This represented a useable data size of 70 SMEs, whilst relationship above five years were considered to be long term relationship representing a useable data size of 129 SMEs. The method of analysis comprises of Principal Component Analysis (PCA) with varimax rotation to determine the discriminant validity of each construct are sufficiently different from each other, subsequently reliability assessment was employed using the Cronbach alpha method to determine the reliability of each set of scale for internal consistency. The next stage of analysis involved the deployment of regression analysis using the forced method approach considering the theoretical establishment of satisfaction and loyalty construct in the literature.

\subsection{Study Findings}

The fourteen items implemented yielded as part of their PCA assessment sufficient factor extractions ranging from 0.66 to 0.85 and loaded in two distinct constructs. The evidence on Table two below indicated acceptance of the constructs for further analysis including the acceptable reliability scores of satisfaction ( 0.90$)$ and loyalty (0.92).

Table 2. Extraction statistics for satisfaction and advocacy

\begin{tabular}{|c|c|c|c|c|c|}
\hline \multirow[b]{2}{*}{ No } & \multirow[b]{2}{*}{ Construct } & \multicolumn{3}{|c|}{ Factor Loadings/ Components } & \multirow[b]{2}{*}{$\begin{array}{l}\text { Standard } \\
\text { Deviation }\end{array}$} \\
\hline & & $\begin{array}{l}\text { Extraction } 1 \\
\text { (Loyalty) }\end{array}$ & $\begin{array}{l}\text { Extraction } 2 \\
\text { (Satisfaction) }\end{array}$ & Mean & \\
\hline 1 & $\begin{array}{l}\text { My company says positive things to other people about my } \\
\text { retail bank. }\end{array}$ & 0.73 & & 5.11 & 1.04 \\
\hline 2 & $\begin{array}{l}\text { My company recommends my retail bank to other companies } \\
\text { (people replaced) that seek advice. }\end{array}$ & 0.85 & & 5.03 & 1.10 \\
\hline 3 & $\begin{array}{l}\text { My company encourages business partners (friends and } \\
\text { relatives replaced) to do business with my retail bank. }\end{array}$ & 0.83 & & 5.09 & 1.13 \\
\hline 4 & $\begin{array}{l}\text { When the topic of my retail banks comes up in conversation, } \\
\text { my company goes out of my way to recommend this bank. }\end{array}$ & 0.80 & & 4.69 & 1.26 \\
\hline 5 & $\begin{array}{l}\text { My company will consider my retail bank as the main bank in } \\
\text { the next few years. }\end{array}$ & 0.71 & & 5.02 & 1.15 \\
\hline 6 & $\begin{array}{l}\text { My company will do more banking with my retail bank in the } \\
\text { next few years. }\end{array}$ & 0.70 & & 5.10 & 1.06 \\
\hline
\end{tabular}




\begin{tabular}{|c|c|c|c|c|c|}
\hline 7 & $\begin{array}{l}\text { My company chances of staying in the relationship with the } \\
\text { bank are very good. }\end{array}$ & 0.66 & & 5.09 & 1.08 \\
\hline 8 & $\begin{array}{l}\text { My company will use my retail bank for all my investment } \\
\text { needs }\end{array}$ & 0.73 & & 5.03 & 1.20 \\
\hline 9 & $\begin{array}{l}\text { In general, my company is very satisfied with my current retail } \\
\text { bank. }\end{array}$ & & 0.78 & 5.18 & 1.06 \\
\hline 10 & Overall, it's been good to bank with my current retail bank. & & 0.81 & 5.21 & 1.02 \\
\hline 11 & Overall, the service of my bank comes up to my expectations. & & 0.85 & 5.04 & 1.14 \\
\hline 12 & Overall, the retail bank treats my company very fairly & & 0.80 & 5.18 & 0.99 \\
\hline
\end{tabular}

The Cronbach's alpha post-hoc reliability assessment of the 4 retained items for satisfaction and 8 retained items for loyalty were all satisfactory with reliability scores of 0.90 and 0.92 respectively, being clearly in excess of the 0.70 threshold value suggested by Hair et al. (2010). Further assessment of the Cronbach's alpha measures achieved through item deletion suggests that no further deletion of any item within the scale set can improve the overall reliability of satisfaction and loyalty scales were identified. The results are documented in Table 3.

Table 3. Reliability assessment of satisfaction and advocacy

\begin{tabular}{lll}
\hline Research Items & Cronbach's alpha Score & Cronbach's alpha Score if Item is deleted \\
\hline Loyalty & 0.92 & 0.92 \\
& & 0.91 \\
& 0.91 \\
& 0.92 \\
& 0.92 \\
& 0.92 \\
& 0.92 \\
& & 0.92 \\
\hline Satisfaction & 0.90 & 0.86 \\
& & 0.86 \\
& & 0.86 \\
& & 0.89 \\
\hline
\end{tabular}

The result from the regression analysis suggests that both short and long term relationship length model were significant at $0.00 \%$. For the short term relationship duration, satisfaction positively predicted loyalty with a variation of $45 \%$. Likewise, for a longer relationship length, satisfaction also had a positive prediction of loyalty with a variation of $43 \%$. The results are documented in Table 4 to 7 respectively.

Table 4. Model summary of relationship age less than five years

\begin{tabular}{lllll}
\hline Variable Entered & $\mathbf{R}$ & $\mathbf{R}^{2}$ & Standard Error of Estimate \\
\cline { 2 - 5 } & Loyalty & 0.67 & 0.45 & 0.73 \\
\hline
\end{tabular}

Note. Predictor $=$ Satisfaction .

Table 5. Coefficients of relationship age of less than five years

\begin{tabular}{lllll}
\hline Model & Unstandardized Coefficients (B) & Standardized Coefficients (B) & t & Sig. \\
\hline (Constant) & 1.37 & & 2.78 & 0.00 \\
Satisfaction & 0.69 & 0.67 & 7.48 & 0.00 \\
\hline
\end{tabular}

Note. Dependent variable: Loyalty.

Table 6. Model summary of relationship age more than five years

\begin{tabular}{llll}
\hline Variable Entered & R & R2 & Standard Error of Estimate \\
\hline Loyalty & 0.65 & 0.43 & 0.67 \\
\hline
\end{tabular}

Note. Predictor $=$ Satisfaction. 
Table 7. Coefficients of relationship age of more than five years

\begin{tabular}{lllll}
\hline Model & Unstandardized Coefficients (B) & Standardized Coefficients (B) & t & Sig. \\
\hline (Constant) & 1.75 & & 5.15 & 0.00 \\
Satisfaction & 0.63 & 0.65 & 9.82 & 0.00 \\
\hline
\end{tabular}

Note. Dependent variable: Loyalty.

\section{Discussion and Conclusion}

The study aim was to investigate within the B2B RM context comprising of the Nigerian SMEs satisfaction impact on their loyalty towards Nigerian bank taking into account relationship length as a key determinant factor in these relationships. The study finding is in resonance to the extant literature that satisfaction contributes fundamentally as a key driver of loyalty in RM. This finding was consistent for both relationship lengths. Surprisingly, this study found no significant difference between the short and long term relationship length of the SMEs banking association with their banks as indicated in Tables 4 to 7 above. This is in contrary to other studies which have found significant impact of relationship length to the sustainability of the relationship. The context of this study provides an indication that perhaps the SMEs continuous patronage of their bank services is not based on how long the SMEs has been but the benefits been derived from their relationship such as technical and financial support.

In terms of contribution, this study extended the relationship framework of satisfaction and loyalty into a new terrain which is clearly under studied in RM.. Furthermore, this study examined the dynamics of the association by assessing relationship length as a key factor in SMEs and bank relationship in Nigeria; this is an area of study that has not been subsequently studied. Therefore the study adds to the body of knowledge in the area of relationship length.

The research also makes substantial practical knowledge to the bank practitioners in the sense that the study identifies that, whist SMEs satisfaction and loyalty were evident based on the mean values on Table 2 above, the consideration of diversity of RL as a relationship driver was mutual, thus bank practitioners should consider maintaining their ongoing strategies of satisfying their customers regardless of the RL through the deployment of technical and loan supports. Alternatively, the banks can take the opposite approach by formulating incentives that will be more attractive to long term customers. For example, the banks can consider giving more financial supports to SMEs whose relationship duration has been for a much longer term than the short relationship counterpart.

\section{References}

Agbonkpolor, T. (2010). Risk management and regulatory failures in banking: Reflections on the current banking crisis in Nigeria. Journal of Banking Regulation, 11(2), 146-155. https://doi.org/10.1057/jbr.2010.5

Andaleeb, S. S., \& Conway, C. (2006). Customer satisfaction in the restaurant industry: an examination of the transaction-specific model. Journal of Services Marketing, 20(1), 3-11. https://doi.org/10.1108/08876040610646536

Anderson, E. W., Fornell, C., \& Lehmann, D. R. (1994). Customer satisfaction, market share, and profitability: findings from Sweden. The Journal of Marketing, 58(7), 53-66. https://doi.org/10.2307/1252310

Anderson, J. C., \& Narus, J. A. (1984). A model of the distributor's perspective of distributor-manufacturer working relationships. Journal of Marketing, 48(4), 62-74. https://doi.org/10.2307/1251511

Ariyo, D. (2008). Small Firms are the backbone of the Nigerian Economy. African Economic Analysis, Academy Management Journal, 1(1).

Auh, S., Bell, S. J., McLeod, C. S., \& Shih, E. (2007). Co-production and customer loyalty in financial services. Journal of Retailing, 83(3), 359-370. https://doi.org/10.1016/j.jretai.2007.03.001

Aydin, S., Ozer, G., \& Arasil, O. (2005). Customer loyalty and the effect of switching costs as a moderator variable: A case in the Turkish mobile phone market. Marketing Intelligence \& Planning, 23(1), 89-103. https://doi.org/10.1108/02634500510577492

Ball, D., Coelho, P. S., \& Machás, A. (2004). The role of communication and trust in explaining customer loyalty: an extension to the ECSI model. European Journal of Marketing, 38(9/10), 1272-1293. https://doi.org/10.1108/03090560410548979

Beck, J. T., Chapman, K., \& Palmatier, R. W. (2015). Understanding relationship marketing and loyalty program 
effectiveness in global markets. Journal of International Marketing, 23(3), 1-21. https://doi.org/10.1509/jim.15.0010

Beck, T., Cull, R., \& Jerome, A. (2005). Bank privatization and performance: Empirical evidence from Nigeria. Journal of Banking \& Finance, 29(8), 2355-2379. https://doi.org/10.1596/1813-9450-3511

Beerli, A., Martin, J. D., \& Quintana, A. (2004). A model of customer loyalty in the retail banking market. European Journal of Marketing, 38(1/2), 253-275. https://doi.org/10.1108/03090560410511221

Bell, S. J., \& Eisingerich, A. B. (2007). The paradox of customer education: customer expertise and loyalty in the financial services industry. European Journal of Marketing, 41(5/6), 466-486, https://doi.org/10.1108/03090560710737561

Bloemer, J. M., \& Kasper, H. D. (1995). The complex relationship between consumer satisfaction and brand loyalty. Journal of Economic Psychology, 16(2), 311-329. https://doi.org/10.1016/0167-4870(95)00007-B

Bloemer, J., \& O dekerken-Schröder, G. (2007). The psychological antecedents of enduring customer relationships: an empirical study in a bank setting. Journal of Relationship Marketing, 6(1), 21-43. https://doi.org/10.1300/J366v06n01_03

Bodet, G. (2008). Customer satisfaction and loyalty in service: Two concepts, four constructs, several relationships. Journal of Retailing and Consumer Services, 15(3), 156-162. https://doi.org/10.1016/j.jretconser.2007.11.004

Boulding, W., Kalra, A., Staelin, R., \& Zeithaml, V. A. (1993). A dynamic process model of service quality: from expectations to behavioral intentions. Journal of Marketing Research, 30(1), 7-27. https://doi.org/10.2307/3172510

Bove, L. L., \& Johnson, 1.W (2000). A customer-service worker relationship model. International Journal of Service Industry Management, 11(5), 491-511. https://doi.org/10.1108/09564230010360191

Caceres, R. C., \& Paparoidamis, N. (2004). Service quality and marketing performance in business-to-business markets: exploring the mediating role of client satisfaction. Managing Service Quality, 14(2/3), 235-248. https://doi.org/10.1108/09604520410528653

Cater, B., \& Zabkar, V. (2009). Antecedents and consequences of commitment in marketing research services: The client's perspective. Industrial Marketing Management, 38(7), 785-797, https://doi.org/10.1016/j.indmarman.2007.10.004

Chaudhuri, A., \& Holbrook, M. B. (2001). The chain of effects from brand trust and brand affect to brand performance: the role of brand loyalty. Journal of Marketing, 65(2), 81-93. https://doi.org/10.1509/jmkg.65.2.81.18255

Day, G. S. (1969). Two-dimensional concept of brand loyalty. Journal of Advertising Research, 9(9), 29-35.

Dick, A. S., \& Basu, K. (1994). Customer loyalty: toward an integrated conceptual framework. Journal of the Academy of Marketing Science, 22(2), 99-113, https://doi.org/10.1177/0092070394222001

Dimitriades, Z. S. (2006). Customer satisfaction, loyalty and commitment in service organizations: some evidence from Greece. Management Research News, 29(12), 782-800. https://doi.org/10.1108/01409170610717817

Ehrenberg, A., \& Goodhardt, G. (2000). New brands: near-instant loyalty. Journal of Marketing Management, 16(6), 607-617. http://dx.doi.org/10.1362/026725700785045912

Evanschitzky, H., Ramaseshan, B., Woisetschläger, D. M., Richelsen, V., Blut, M., \& Backhaus, C. (2012). Consequences of customer loyalty to the loyalty program and to the company. Journal of the Academy of Marketing Science, 40(5), 625-638.

Fournier, S., \& Mick, D.G. (1999). Rediscovering Satisfaction. Journal of Marketing, 63(10), 5-23. https://doi.org/10.2307/1251971

Fullerton, G. (2011). Creating advocates: the roles of satisfaction, trust and commitment. Journal of Retailing and Consumer Services, 18(1), 92-100. https://doi.org/10.1016/j.jretconser.2010.10.003

Garbarino, E., \& Johnson, M. S. (1999). The different roles of satisfaction, trust, and commitment in customer relationships. The Journal of Marketing, 63(4) 70-87. https://doi.org/10.2307/1251946

Geyskens, I., Steenkamp, J. B. E. M., \& Kumar, N. (1999). A Meta-Analysis of Satisfaction in Marketing Channel Relationships. Journal of Marketing Research (JMR), 36(2), 223-238. 
https://doi.org/10.2307/3152095

Gremler, D. D., \& Gwinner, K. P. (2000), Customer-employee rapport in service relationships. Journal of Service Research, 3(1), 82-104. https://doi.org/10.1177/109467050031006

Grönroos, C. (1994). Quo vadis, marketing? Toward a relationship marketing paradigm. Journal of Marketing Management, 10(5), 347-360. http://dx.doi.org/10.1080/0267257X.1994.9964283

Gummerus, J., Liljander, V., Pura, M., \& Van Riel, A. (2004). Customer loyalty to content-based web sites: the case of an online health-care service. Journal of Services Marketing, 18(3), 175-186. https://doi.org/10.1108/08876040410536486

Gummesson, E. (2002). Relationship marketing in the new economy. Journal of Relationship Marketing, 1(1), 37-57. https://doi.org/10.1108/08876040210447315

Hair, J. F., Black, W. C., Babin, B. J., \& Anderson, R. E. (2010). Multivariate Data Analysis-A Global Perspective (7th ed.). New Jersey: Pearson Education.

Hellier, P. K., Geursen, G. M., Carr, R. A., \& Rickard, J. A. (2003). Customer repurchase intention: a general structural equation model. European Journal of Marketing, 37(11/12), 1762-1800. https://doi.org/10.1108/03090560310495456

Homburg, C., \& Giering, A. (2001). Personal characteristics as moderators of the relationship between customer satisfaction and loyalty-an empirical analysis. Psychology \& Marketing, 18(1), 43-66. https://doi.org/10.1002/1520-6793(200101)18:1<43::AID-MAR3>3.0.CO;2-I

Homburg, C., \& Stock, R. M. (2004). The link between salespeople's job satisfaction and customer satisfaction in a business-to-business context: A dyadic analysis. Journal of the Academy of Marketing Science, 32(2), 144-158. https://doi.org/10.1177/0092070303261415

Homburg, C., Koschate, N., \& Hoyer, W. D. (2005). Do Satisfied Customers Really Pay More? A Study of the Relationship Between Customer Satisfaction and Willingness to Pay. Journal of Marketing, 69(4), 84-97. https://doi.org/10.1509/jmkg.69.2.84.60760

Hutchinson, D., Wellington, W. J., Saad, M., \& Cox, P. (2011). Refining value-based differentiation in business relationships: A study of the higher order relationship building blocks that influence behavioural intentions. Industrial Marketing Management, 40(3), 465-478. https://doi.org/10.1016/j.indmarman.2010.08.010

Jacoby, J., \& Kyner, D. B. (1973). Brand loyalty vs. repeat purchasing behaviour. Journal of Marketing Research, 10(2), 1-9. https://doi.org/10.2307/3149402

Johnson, M. D., Anderson, E. W., \& Fornell, C. (1995). Rational and adaptive performance expectations in a customer satisfaction framework. Journal of Consumer Research, 21(4), 128-140. https://doi.org/10.1086/209428

Johnson, M. D., Gustafsson, A., Andreassen, T. W., Lervik, L., \& Cha, J. (2001). The evolution and future of national customer satisfaction index models. Journal of Economic Psychology, 22(2), 217-245. https://doi.org/10.1016/S0167-4870(01)00030-7

Jones, M. A., \& Suh, J. (2000). Transaction-specific satisfaction and overall satisfaction: an empirical analysis. Journal of Services Marketing, 14(2), 147-159. https://doi.org/10.1108/08876040010371555

Jones, M. A., Reynolds, K. E., Mothersbaugh, D. L., \& Beatty, S. E. (2007). The positive and negative effects of switching costs on relational outcomes. Journal of Service Research, 9(4), 335-355. https://doi.org/10.1177/1094670507299382

Knox, S., \& Walker, D. (2001). Measuring and managing brand loyalty. Journal of Strategic Marketing, 9(2), 111-128. https://doi.org/10.1080/713775733

Kumar, N., Hibbard, J. D., \& Stern, L. W. (1994). An empirical assessment of the nature and consequences of marketing channel intermediary commitment. Report No. 94-115. Cambridge, MA: Marketing Science Institute.

Lam, S. Y., Shankar, V., Erramilli, M. K., \& Murthy, B. (2004). Customer value, satisfaction, loyalty, and switching costs: an illustration from a business-to-business service context. Journal of the Academy of Marketing Science, 32(3), 293-311. https://doi.org/10.1177/0092070304263330

National Bureau of Statistics and Small and Medium Enterprises Development Agency of Nigeria. (2010). Survey report on micro, small and medium enterprises in Nigeria. Retrieved from 
www.nigerianstat.gov.ng/pages/download/67

Odin, Y., Odin, N., \& Valette-Florence, P. (2001). Conceptual and operational aspects of brand loyalty: an empirical investigation. Journal of Business Research, 53(2), 75-84. https://doi.org/10.1016/S0148-2963(99)00076-4

Ogba, I. E. (2008). Commitment in the workplace: the impact of income and age on employee commitment in Nigerian banking sector. Management Research News, 31(11), 867-878. https://doi.org/10.1108/01409170810913051

Oliva, T. A., Oliver, R. L., \& MacMillan, I. C. (1992). A catastrophe model for developing service satisfaction strategies. The Journal of Marketing, 56(7), 83-95. https://doi.org/10.2307/1252298

Oliver, R. L. (1980). A cognitive model of the antecedents and consequences of satisfaction decisions. Journal of Marketing Research, 17(4), 460-469. https://doi.org/10.2307/3150499

Oliver, R. L. (1999). Whence consumer loyalty? The Journal of Marketing, 63(4), 33-44. https://doi.org/10.2307/1252099

Oliver. (1997). Satisfaction: a behavioral perspective on the consumer. US: Mcgraw.

Olsen, S. O. (2007). Repurchase loyalty: the role of involvement and satisfaction. Psychology \& Marketing, 24(4), 315-341. https://doi.org/10.1002/mar.20163

Palmatier, R. W., Dant, R. P., Grewal, D., \& Evans, K. R. (2006). Factors influencing the effectiveness of relationship marketing: a meta-analysis. Journal of Marketing, 70(4), 136-153. https://doi.org/10.1509/jmkg.70.4.136

Patterson, P. G., Johnson, L. W., \& Spreng, R. A. (1996). Modeling the determinants of customer satisfaction for business-to-business professional services. Journal of the Academy of Marketing Science, 25(1), 4-17. https://doi.org/10.1177/0092070397251002

Rauyruen, P., \& Miller, K. E. (2007). Relationship quality as a predictor of B2B customer loyalty. Journal of Business Research, 60(1), 21-31. https://doi.org/10.1016/j.jbusres.2005.11.006

Rauyruen, P., Miller, K. E., \& Groth, M. (2009). B2B services: linking service loyalty and brand equity. Journal of Services Marketing, 23(3), 175-186. https://doi.org/10.1108/08876040910955189

Reichheld, F. (2006). The ultimate question. Boston, MA.: Harvard Business School Press.

Reichheld, F. F. (1994). Loyalty and the renaissance of marketing. Marketing Management, 2(4), 10-21.

Reichheld, F. F. (2003). The one number you need to grow. Harvard Business Review, 81(12), 46-55.

Roman, S. (2003). The impact of ethical sales behaviour on customer satisfaction, trust and loyalty to the company: An empirical study in the financial services industry. Journal of Marketing Management, 19(9-10), 915-939. http://dx.doi.org/10.1080/0267257X.2003.9728245

Shankar, V., Smith, A. K., \& Rangaswamy, A. (2003). Customer satisfaction and loyalty in online and offline environments. International Journal of Research in Marketing, 20(2), 153-175. https://doi.org/10.1016/S0167-8116(03)00016-8

Sheth, J. N., \& Parvatiyar, A. (2002). Evolving relationship marketing into a discipline. Journal of Relationship Marketing, 1(1), 3-16. http://dx.doi.org/10.1300/J366v01n01_02

Spreng, R. A., \& Mackoy, R. D. (1996). An empirical examination of a model of perceived service quality and satisfaction. Journal of retailing, 72(2), 201-214. https://doi.org/10.1016/S0022-4359(96)90014-7

Uche, C. U., \& Ehikwe, A. E. (2001). Marketing of banking services in Nigeria. Journal of Financial Services Marketing, 6(2), 133-146. https://doi.org/10.1057/palgrave.fsm.4770047

Veloutsou, C., Gilbert, G. R., Moutinho, L. A., \& Goode, M. M. (2005). Measuring transaction-specific satisfaction in services: are the measures transferable across cultures? European Journal of Marketing, 39(5/6), 606-628. https://doi.org/10.1108/03090560510590737

Wallace, D. W., Giese, J. L., \& Johnson, J. L. (2004). Customer retailer loyalty in the context of multiple channel strategies. Journal of Retailing, 80(4), 249-263. https://doi.org/10.1016/j.jretai.2004.10.002

Wang, C. Y., \& Wu, L. W. (2012). Customer loyalty and the role of relationship length. Managing Service Quality: An International Journal, 22(1), 58-74. https://doi.org/10.1108/09604521211198119

Yi, Y., \& La, S. (2004). What influences the relationship between customer satisfaction and repurchase intention? 
Investigating the effects of adjusted expectations and customer loyalty. Psychology \& Marketing, 21(5), 351-373. https://doi.org/10.1002/mar.20009

Zeithaml, V. A., Berry, L. L., \& Parasuraman, A. (1996). The behavioral consequences of service quality. The Journal of Marketing, 49(2), 31-46. https://doi.org/10.2307/1251929

Zhang, J., Watson, G. IV., Palmatier, R., \& Dant, R. (2016). Dynamic Relationship Marketing. Journal of Marketing, 80(5), 53-75. http://dx.doi.org/10.1509/jm.15.0066

\section{Copyrights}

Copyright for this article is retained by the author, with first publication rights granted to the journal.

This is an open-access article distributed under the terms and conditions of the Creative Commons Attribution license (http://creativecommons.org/licenses/by/4.0/). 